\title{
Revisiting Tilly's Thesis: \\ Is War Still Useful for State-making and State-consolidation?
}

\author{
Yoon, Tae-Ryong \\ (Jeju Peace Institute)
}

\section{$\langle$ CONTENTS〉}

I. Introduction

II. War, Militarization (=Civilianization), State Consolidation, and Development of Capitalism

III. War and Its Ambivalent Effects

1. War, Taxation, and Ratchet Effect versus Negative Displacement Effect

2. War, Public Good, Mobilization, and War's Diminishing Benefits

3. War, Need for High-tech Weapons, and the Third World's Political Dependence on Great Powers
4. Threatening versus Non-threatening Wars: Their Different Effects on Cohesion

5. Summary

IV. Towards Conditional

Generalization on War's Role

1. Variations in Europe's Historical Experiences

2. Historical Experiences Outside of Europe

3. Beyond European Experiences Towards Comprehensive Understanding

V. Conclusion

- Keyword: war, state-building, state-making, state-consolidation, coercion, capitalism, Charles Tilly, Third World states, Europe's state-building

\section{【ABSTRACT】}

"War made the state, and the state made the war." This powerful statement of Charles Tilly's, which is based on the history of European experiences, if it turns out to be right in general, will lead us to believe war is a 'necessary evil' for human progress and that war in the Third World is a good thing in the long run because it consolidates a state's apparatuses necessary not only for keeping order in a country but also for managing people's lives efficiently in a society. In a corollary of this logic, with regard to the failed states in Africa, Jeffrey Herbst

* I thank Barnett R. Rubin and Michael Desch, respectively for introducing the subject to me for the first time, and for calling my attention to the recent scholarly development as well as encouraging me to go ahead. I also thank Bong-Jun Ko, Seong-Woo Yi, and the three anonymous reviewers for useful comments on earlier drafts. 
argues that developing countries cannot accomplish in times of peace what war enabled European countries to do. This argument seems to be counterintuitive if we consider the devastating and tragic effects of war on human conditions during the war and thereafter. Then, should we prefer war to peace or vice versa? Through literature review including the recently added studies by Brian Downing, Thomas Ertman, Victoria Tin-bor Hui, Miguel Angel Centeno, and Richard Boyd \& Tak-Wing Ngo, this essay concludes that there is no general rule that wars play and will play the same positive role in state-making and state-consolidation in the Third World countries including Asian, Latin American and African countries as the past wars often did in Europe. Even the history of European experiences should be further scrutinized.

\section{Introduction}

This is not an original research paper, but a review paper on the relationship between war $^{1)}$ and state-making and state-consolidation, which is necessary both for checking the present state of scholarship on the subject and for conducting theoretically meaningful research.

War (or fears of possible war) could have multiple effects.

For instance, Realist theory, including Stephen Walt's balance-of-threat theory, ${ }^{2)}$ assumes that states with common threats have a tendency to cooperate by aligning or allying themselves to increase their relative 'aggregate power ${ }^{\text {') }}$ and balance against the

1) Here I define war broadly as "armed conflict between countries or groups." Therefore, wars refer to not only interstate wars but also intrastate (or civil) wars. Therefore, I do not focus on a specific type of war, but deal with any types of war as external threat with some negative and positive effects on making and consolidation of states.

2) Stephen M. Walt, The Origins of Alliances (Ithaca and London: Cornell University Press, 1987); idem, "Alliances in Theory and Practice: What Lies Ahead?" Journal of International Affairs, Vol.43, No.1 (Summer-Fall 1989); idem, "Alliance Formation in Southwest Asia: Balancing and Bandwagoning in Cold War competition," Robert Jervis and Jack Snyder, ed., Dominoes and Bandwagons: Strategic Beliefs and Great Power Competition in the Eurasian Rimland (New York/Oxford: Oxford University Press, 1991).

3) A state may ally with another not primarily to aggregate power capabilities against a common threat but to gain influence over the ally and perhaps restrain it from taking certain actions that might be contrary to the first state's interests. See Jack S. Levy and Michael Barnett, "Domestic Sources of Alliances and Alignment: the Case of Egypt, 1962-73," International Organization, Vol.45, No.3 (Summer 1991), 371; Also see Paul W. Schroeder, 
external threats. Walt emphasizes and demonstrates the causal importance of perceived threats $^{4)}$ in alliance formation. According to Glenn Snyder, however, Walt's study is principally about alliance formation rather than the politics of alliances after they form. ${ }^{5}$ Snyder bridges this theoretical gap with the theory of 'security dilemma' in intra-alliance politics after alliance formation, which provides a theory of alliance management or alliance bargaining. ${ }^{6)}$ In short, fears of war (or increased threat) could increase interstate or external cooperation-alliance formation and mutual supports among allies once alliance is formed-against the common threat.

However, fears of war could also increase internal cooperation and cohesion within a country. As Migdal points out, the influence of war on state-society relations is an important issue which still needs full study of its own. ${ }^{7)}$ This is a sub-issue of the broader one: the impact of the external factors on domestic politics, which was earlier theorized by Seeley and Hintze. ${ }^{8)}$ Seeley once presented the general rule that "intense government is the reaction against intense pressure." ${ }^{9)}$ This rule can be said to be supported by Tilly's analysis of European history, which is characterized by his succinct thesis: "War made the state, and the state made the war."

Many scholars accept that a group's (or a state's) involvement in an external conflict increases its internal cohesion (or national unity). Herbst even argues that "they [developing countries] probably cannot [accomplish in times of peace what war enabled European countries to do] because fundamental changes in economic structures and societal beliefs are difficult, if not impossible, to bring about when countries are not

"Alliances, 1815-1945: Weapons of Power and Tools of Management," Klaus Knorr, ed., Historical Dimensions of National Security Problems (Lawrence: Published for the National Security Education Problem by the University Press of Kansas, 1976).

4) For a good discussion of threat perception, see Klaus Knorr, "Threat Perception," Klaus Knorr, ed., Historical Dimensions of National Security Problems, 79-119.

5) Glenn H. Snyder, "Alliance Theory: A Neorealist First Cut," Journal of International Affairs, Vol.44, No.1 (Spring 1990); idem, "Alliances, Balance, and Stability," International Organization, Vol.45, No.1 (Winter 1991), 125.

6) Glenn H. Snyder, Alliance Politics (Ithaca and London: Cornell University Press, 1997); idem, "The Security Dilemma in Alliance Politics," World Politics, Vol.36, No.4 (July 1984).

7) Joel S. Migdal, Strong Societies and Weak States: State-Society Relations and State Capabilities in the Third World (Princeton, New Jersey: Princeton University Press, 1988), xvvii, footnote.

8) Gabriel A. Almond, "The International-National Connection," A Discipline Divided: Schools and Sects in Political Science (Newbury Park, London, New Delhi: Sage Publications, 1990); Otto Hintze, "Military Organization and the Organization of the State" Felix Gilbert, ed., The Historical Essays of Otto Hintze (NY: Oxford University Press, 1975).

9) John Robert Seeley, An Introduction to Political Science (London: Macmillan, 1886), 134.

10) Charles Tilly, "Reflections on the History of European State-Making," Charles Tilly, ed., The Formation of National States in Western Europe (Princeton University Press, 1975), 45. 
being disrupted or under severe external threat." ${ }^{11)}$ Corollary to this analysis, with regard to the failed states in Africa, Herbst grimly concludes that it is a mistake to lay emphasis on resuscitating states that have never demonstrated the capacity to be viable. ${ }^{12)}$ These arguments are hard to disprove as we should analyze the effect of a usually "missing factor or non-event"-interstate war-on state-society relations in most of the Third World countries and as we should often rely on counterfactual analysis. ${ }^{13)}$

This essay will first review earlier works on the influence of war on state-society relations while pointing out the danger of sweeping generalization and focusing on war's ambivalent effects (sections $\mathbb{I} \& \mathbb{I}$ ), which induces us to believe even the European experiences leave room for us to see Tilly's thesis from a critical perspective. Then it will briefly review the recently added literature on state formation $(\operatorname{section} I)$, which leads us to realize we need further research for conditional generalization on war's role in the whole world, not just in a specific region of the world. Finally, it will reach a conclusion (section $V$ ) that although we cannot deny the significant role wars did play in the process of state formation and consolidation, the literature leads us to infer there is no general rule that wars always play and will play the same positive role in state-making and state-consolidation in the Third World countries including Asian, Latin American and African countries as the past wars often did in Europe. ${ }^{14)}$

\section{War, Militarization (=Civilianization), State Consolidation, and Development of Capitalism}

The positive role of war in the process of state consolidation?or the "bellicist" view on state formation?is not a new topic. As Huntington put it early in 1968,

11) Jeffrey Herbst, "War and the State in Africa," International Security, Vol.14, No.4 (Spring 1990), 118.

12) Jeffrey Herbst, "Responding to State Failure in African," International Security, Vol.21, No.3 (Winter 1996/97), 144. For a critique of Herbst's argument, see Richard Joseph and Jeffrey Herbst, "Correspondence: Responding to State Failure in Africa," International Security, Vol.22, No.2 (Fall 1997), 175-181.

13) James D. Fearon, "Counterfactuals and Hypothesis Testing in Political Science," World Politics, Vol.43, No.2 (January 1991); Philip E. Tetlock, and Aaron Belkin, ed., Counterfactual Thoughts Experiments in World Politics: Logical, Methodological, and Psychological Perspectives (Princeton, New Jersey: Princeton University Press, 1996).

14) For obsolescence of war among developed countries, see John Mueller, Retreat from Doomsday: The Obsolescence of Major War (BasicBooks, 1989). 
The prevalence of war directly promoted political modernization. Competition forced the monarchs to build their military strength. The creation of military strength required national unity $\cdots$, the expansion of armies and bureaucracies, and a major increase in state revenues. $\cdots$ War was the great stimulus to state building. ${ }^{15}$

In light of Huntington's words, therefore, Tilly's above thesis is not a new one although Tilly supports it with a more powerful logic. Giddens also recounts the effects of World War I: "The war centralized the development of states' sovereignty, tying this to citizenship and to nationalism in such a profound way." ${ }^{{ }^{16)}}$

There are also arguments for the positive relationship between war and capitalism. For instance, first, Hall argues that "war in Western European history played a significant role in the triumph of capitalism." ${ }^{17)}$ He further elaborates that the development of capitalism is dependent upon the types of state that wage war. Only in Europe could the "organic" states develop capitalism, unlike China (capstone state), India (custodial state), or the Islam world (cyclical state). Second, Mann defines militarism as "an attitude and a set of institutions which regard war and the preparation for war as a normal and desirable social activity." ${ }^{18)}$ He sees that militarism was necessary for capitalism and the multi-state system. In a similar way, Tilly identifies the process of militarization with that of civilianization of government (MILITARIZATION=CIVILIANIZATION). Schematically, the state transformation occurred in the four stages of patrimonialism, brokerage, nationalization, and specialization. ${ }^{19)}$ As Tilly puts it,

[F]irst, a period in which major powerholders themselves were active military men, recruiting and commanding their own armies and navies; then the heyday of military entrepreneurs and mercenary troops in the hire of civilian powerholders; followed by the incorporation of the military structure into the state with the creation of standing

15) Samuel P. Huntington, Political Order in Changing Societies (New Haven and London: Yale University Press, 1968), 122-123. For earlier argument (or hypothesis) that we are moving toward a world of garrison states - a world in which the specialists on violence are the most powerful group in society, see Harold D. Lasswell, "The Garrison State," The American Journal of Sociology, Vol.46, No.4 (January 1941).

16) Anthony Giddens, The Nation State and Violence: Volume Two of a Contemporary Critique of Historical Materialism (Berkeley: University of California Press, 1987), 235.

17) John A. Hall, "War and the Rise of the West," Colin Creighton and Martin Shaw, eds., The Sociology of War and Peace (London: Macmillan, 1987), 37.

18) Michael Mann, "Capitalism and Militarism," Michael Mann, States, War and Capitalism (Basil Blackwell, 1988), 124.

19) Charles Tilly, Coercion, Capital, and European States, AD 990-1990 (Cambridge, Massachusetts: Basil Blackwell, 1990), 122-126. 
armies; and finally, the shift to mass conscription, organized reserves, and well-paid volunteer armies drawn essentially from the state's own citizenry. ${ }^{20)}$

Therefore, the argument that war is inimical to human progress ${ }^{211}$ is strongly challenged by many scholars. Simply speaking, the challenging logic is that war as a great external threat promoted national unity [nationalism], restrained the internal resistance to increased taxation [extraction] in the process of war-preparation, helped capital accumulation [capitalist development], and eventually formed and consolidated the states and the system of nation-states. ${ }^{22)}$

If one crudely applies this analysis to the Third World countries, one might argue that war is necessary and indispensable for the consolidation of states and capitalist development in the Third World. As it were, the logic can be summarized as "no interstate war, no state building; no state building, no development" in Joseph's words. ${ }^{23)}$

Actually, Herbst argues that "it should be obvious that the incentives that African leaders have to incite wars for the purposes of state-making are significant and may become much stronger in the future when the futility of domestic reform during the times of business as usual, that is peace, becomes clear." ${ }^{44)}$ This essay was stimulated by (and was motivated to argue against) Herbst's single-minded attention to the bright side of war. He says, "It is important not to glorify war. ‥ No one would advocate war as a solution to Africa's political and economic problems." Nevertheless, he reaches a dismal conclusion that "there is very little evidence that African countries, or many others in the Third World, will be able to find peaceful ways to strengthen the state and develop national identities. ${ }^{25)}$ As a result, he strongly implies that there is no other way than war for the consolidation of the Third World states because that's the way the European states were formed, though he said, "I reject the charge that I am inciting the violence that has done so much damage to African countries." However, Herbst needs to pay more attention to the other Third World states before reaching a concluding.

Several caveats are in order at this juncture.

20) Ibid., 122.

21) For an earlier negative view of war, see J.U. Nef, War and Human Progress (Cambridge, Mass.: Harvard University Press, 1950).

22) Spruyt argues that nation-states and territorially sovereign powers were not the only possible forms. At the end of the Middle Ages there were varieties of alternatives. See Hendrik Spruyt, The Sovereign State and Its Competitors: An Analysis of Systems Change (Princeton, NJ: Princeton University Press, 1994).

23) Joseph and Herbst, "Correspondence: Responding to State Failure in Africa," 175-176.

24) Herbst, "War and the State in Africa," 136.

25) Ibid., 138. 
First, as Jervis puts it, "only rarely does a single factor determine the way politics will work out. Even the best propositions are couched in terms of conditions and probabilities." ${ }^{26)}$ Therefore, we should be cautious not to make a sweeping generalization regarding the relationship of war and state-consolidation. Under different conditions and circumstances war could disturb as well as consolidate the state.

Second, "learning about politics can act as a self-fulfilling prophecy" or theories themselves can produce self-fulfilling prophecy if actors pay attention to academic theories and their behaviors. ${ }^{27)}$ If a state's elites believe in the theory that "war made and will make and consolidate the state," it is highly likely that they will resort to war. However, this kind of application is very absurd and dangerous since the effects of war on state, society, and state-society relations have not been thoroughly analyzed yet.

Third, time and place factors should be considered. Even if it is true that wars often consolidated the states in Europe in the past, it does not mean that future wars will continue to play the same role in Europe (or in developed countries). Nor does it mean that wars will consolidate the states in the Third world countries in the future as wars did in Europe. Tilly himself warns that "Third World state formation should be distinctively different." ${ }^{28)}$

\section{War and Its Ambivalent Effects}

\section{War, Taxation, and Ratchet Effect versus Negative Displacement Effect}

Peacock and Wiseman show that the growth of public expenditures in England was influenced by the impact of war. They argue that national crises, particularly war, changed public expectations about the legitimacy of levels of taxation. Government found that popular uses for these increased revenues and thus public expenditures, having been "ratcheted up" by costly wars, never returned to their prewar levels. ${ }^{29}$

Similarly, in an analysis of the relationship between war-making and state-making Thompson and Rasler conclude: First, the relationship between global war and permanent spending shifts is significant. Global war must therefore be considered one

26) Robert Jervis, "The Future of World Politics: Will It Resemble the Past?" International Security, Vol.16, No.3 (Winter 1991/92), 40.

27) Ibid., 40. Also see Robert Jervis, System Effects: Complexity in Political and Social Life (Princeton, New Jersey: Princeton University Press, 1997), 47.

28) Tilly, Coercion, Capital, and European States, AD 990-1990, 195.

29) Almond, A Discipline Divided: Schools and Sects in Political Science, 274-275. 
of the most important sources of the growth and expansion of the modern state. Second, the spending and tax revenue patterns and the organizational expansion of states are more likely to be displaced permanently by global war than they are by interstate wars. This suggests they recognize that different kinds of wars could have different effects on the taxation problem. ${ }^{30}$

However, Thompson and Rasler could neither confirm nor disconfirm Peacock and Wiseman's idea once and for all that national crises provide opportunities for overcoming taxpayer resistance to greater revenue extraction efforts despite the former' s conclusion that an appreciation for the persistent role of war is central to explaining the growth and expansion of the state. ${ }^{31)}$

The "ratchet effect" occurs for three reasons: First, the wartime increase in state power gives officials new capacity to extract resources, take on new activities, and defend themselves against cost-cutting. Second, wars either cause or reveal new problems that call for state attention. Third, the wartime accumulation of debt places new burdens on the state. ${ }^{32)}$ Stein calls this a "positive displacement effect" meaning that war's end brings a re-equilibrium of revenues to a plateau higher than before the war. ${ }^{33)}$

Herbst argues that war affects state finances for two reasons: First, it puts tremendous strains on leaders to find new and more regular sources of income. Second, citizens are much more likely to acquiesce to increased taxation when the nation is at war than usual because threat to their survival will overwhelm other concerns that they might have about increased taxation. ${ }^{34)}$

Considering all of the discussions above, we may easily conclude that certainly there are strong and positive effects of war on state consolidation because war raises taxes and extends government activities. It is even argued that "fighting wars may be the only way whereby it is possible to have people pay more taxes and at the same time feel more closely associated with the state." ${ }^{35)}$

Nevertheless, if the state is large enough and the war is small enough, political leaders can instead choose to divert already extracted resources to the war effort. For instance,

30) William R. Thompson and Karen A. Rasler, "War Making and State Making: Governmental Expenditures, Tax Revenues, and Global Wars," American Political Science Review, Vol.79, No.2 (June 1985), 504-505.

31) Ibid., 504-505.

32) Tilly, Coercion, Capital, and European States, AD 990-1990, 89.

33) Arthur A. Stein, The Nation at War (Baltimore and London: The Johns Hopkins University Press, 1978, 1980), 90.

34) Herbst, "War and the State in Africa," 120.

35) Ibid., 122. 
during the Vietnam War American leaders did not newly extract most of the resources needed for the war. Moreover, although most resources required for war are not specifically mobilized for the war effort, people still expect their wartime sacrifices to let up at war's end even when those taxes are "old" ones (and not "new" ones for the war purpose). Thus, the end of war leads to a drop in the size of the state to below its prewar level. This is called "negative displacement effect." ${ }^{36)}$

\section{War, Public Geod, Mobilization, and War's Diminishing Benefits}

Mann divides Western history into three phases. The characteristics of each phase can be summarized as follows: ${ }^{377}$

1) HISTORICAL PHASE-1 (PRE-1780): Making war and peace was formally the private prerogative of the medieval prince. However, in reality war also required the feudal levies of the nobility or their consent to taxation. War remained profitable because of spectacular European expansion and because it was not particularly devastating. ${ }^{38)}$

2) HISTORICAL PHASE-2 (1780-1945): The Industrial Revolution converted the territories of the major states into full-fledged 'civil societies.' The war became a 'people's war' and the people wanted victory even at the cost of slaughter. The people sacrificed themselves, but not for nothing. A bargain was struck, fairly explicitly: at the end of the war there would be an extension of the franchise (probably including women) and welfare reforms. The entry of the working class, and of women, into citizenship was accelerated by mass mobilization warfare.

3) HISTORICAL PHASE-3 (POST-1945): One of the historical legacies, war as profitable and rational, has ended. The popular equation of citizenship with war mobilization ended around 1950. It is not likely to be revived, given the nature of war today.

Therefore, Mann also has in mind the different kinds of wars with different effects. Since the end of World War II, war came to be no more profitable. That is, the effects of war in past European history are not the same as those of today.

Moreover, Shaw criticizes Mann's concept of 'people's war' or 'citizen war' which

36) Stein, The Nation at War, 90.

37) Michael Mann, "War and Social Theory: Into Battle with Classes, Nations and States," Colin Creighton and Martin Shaw, eds., The Sociology of War and Peace (London: Macmillan, 1987), 60-70.

38) For discussion of variants of wars in European history (wars of the knights [mercenaries, merchants, professionals, revolution, nations, and technologists]), see Michael Howard, War in European History (New York: Oxford University Press, 1976). 
assumes that citizens in most states "benefited" from the outcome of World War $\mathbb{I}$ in Mann's HISTORICAL PHASE-2. Shaw argues that this benefit from the war was not the result of the inner logic of citizen war. It is rather the result of victory of one model of mobilization for total war (democracy) over another model (fascism). Total war is at best a two-way process, in which the state coerces the population while the population also improves its position in and influence on the state. At worst only the coercive side remains as in the cases of Nazi Germany, Imperial Japan and Stalinist Russia. ${ }^{39)}$

The population always "participates" in total war in the sense that it is mobilized, used, forced to work, fight and die for the state. However, it does not always "participate" in the sense of being able to influence the aims and conduct of war, or of enhancing its post-war influence on social and economic organization or its post-war social rights. Therefore, Mann's concept of 'citizen war' is over-generalization in light of Shaw's argument.

In a similar vein, Price shows the limitations of the changes in women's lives as a result of war work. ${ }^{40)}$ Beckett also argues it is necessary to place wartime change and development within the context of long-term social trends. This would suggest that female suffrage would have come to Britain irrespective of the impact of World War I . Therefore, it is important to judge how far changes survived the immediate postwar situation that generated them and how far such changes would have occurred in any case, ${ }^{41)}$ which requires counter-factual analysis.

In the past, war was justified by the state elites as providing public good [defense or security]. Mobilization [taxation and conscription] was also accepted by the people either because war was not so destructive, or because war was expected to bring about civil rights at war's end at least in some cases. However, since 1945, war as a state's policy option stopped attracting the population in the society. Since war has come to be so destructive, individuals within a society became more reluctant to contribute to the state's war efforts in the form of conscription, taxation and levies. In other words, the high probability of individual sacrifices has increased the incentive for 'free-riding' and decreased war's traditional function of consolidating national unity. Therefore, it is not

39) Martin Shaw, "The Rise and Fall of the Military-Democratic State: Britain 1940-85," Colin Creighton and Martin Shaw, eds., The Sociology of War and Peace (London: Macmillan, 1987), 146-147.

40) Kath Price, "What did you do in the War, Mam?: Woman Steelworkers at the Consett Iron Company during the Second World War," Colin Creighton and Martin Shaw, eds., The Sociology of War and Peace (London: Macmillan, 1987), 178-195.

41) Ian F.W. Beckett, "Total War," Clive Emsley, Arthur Marwick, and Wendy Simpson, ed., War, Peace and Social Change in Twentieth Century Europe (Milton Keynes-Philadelphia: Open University Press, 1989), 43. 
reasonable to jump to the conclusion that 'war does or will consolidate the state' in the future, based on the fact that 'war did consolidate the state' in the past.

\section{War, Need for High-tech Weapons, and the Third World's Political Dependence on Great Powers}

Pointing out the existence of a serious military threat from outside or from other communal groups in the country as a sufficient condition for the emergence of strong state, Migdal says, "War itself and the threat of war induce state leaders to take unusual risks to consolidate social control, creating a strong state." In this vein Israel, Cuba, Vietnam, and the two Koreas are good examples because they have been actually invaded at least once since World War $\mathbb{I} .{ }^{42)}$ Herbst agrees on this sort of view by saying that "the South Korean and Taiwanese states have been able to extract so many resources from their societies in part because the demands to be constantly vigilant provoked the state into developing efficient mechanisms for collecting resources and controlling dissident groups." ${ }^{43)}$

However, we should also look at the other side of the same coin. Today's war technology is qualitatively different from that of the past. The evolution of high technology armaments and the militarization of space have profound and disquieting implications for the Third World countries. Along this line Hoag points at five serious effects: (1) undermining of non-alignment and independence from superpowers; (2) limited access to useful technologies; (3) destabilization; (4) increased neo-colonial pressure; (5) increased suffering during indigenous revolts. ${ }^{44)}$

Let's imagine a Third World country which is facing external threat. Does this situation always lead the state to consolidate its power and make it possible for the state to extract more resources from the society while maintaining national unity at the same time? The answer could be negative.

A small country under external threat is pressured to build up armaments for its national security. ${ }^{45}$ Massive introduction of high technology weaponry makes simple arms insufficient for self-defense. Simple arms of even a decade ago are no match for

42) Migdal, Strong Societies and Weak States, 273-274.

43) Herbst, "War and the State in Africa," 121.

44) Paul W. Hoag, "Hi-Tech Armaments, Space Militarization and the Third World," Colin Creighton and Martin Shaw, eds., The Sociology of War and Peace (London: Macmillan, 1987), 83.

45) For a good discussion of "Guns-and-butter dilemma," see Robert Powell, "Guns, Butter, and Anarchy," American Political Science Review, Vol.87, No.1 (March 1993). 
contemporary weaponry, particularly if the potential enemy has acquired or is likely to acquire higher quality arms. In this situation the country under pressure will purchase high quality weapons from great powers. However, this is not the end of the story of spending. Training and spare parts will require more money. It is said that "the finance minister is under the delusion that when he buys the airplane his problems are over when in fact he's only made a 20 percent down payment on the lifetime cost of the plane." ${ }^{46)}$ In reality, few small nations can afford high quality armaments. To obtain such weapons they must have credits and military assistance which comes only at a political cost, only for a political purpose.

According to Hoag's analysis, even if a Third World country could climb very high up the technological weaponry ladder under some circumstances, it might be forced to strike a political deal with the great powers. It is therefore extremely difficult for a Third World country to obtain the highest quality of weaponry and remain totally nonaligned. That is, at some point the most robust high-technology weaponry can be obtained only at the political cost of depending on the great powers. Limited access to high technology (for instance, satellite communication which is critically important for command, control and intelligence) makes the small country more dependent on the great powers. Modern weapons are frighteningly expensive. Therefore, the need or desire to acquire modern weapons will have a destabilizing influence in the Third World because of its increasing dependence on great powers and financial strain.

In a nutshell, today's war cannot be won without high technology weaponry, which is too expensive. Therefore, there is a high probability that war-preparation will destabilize the state rather than consolidate it. Of course, this doesn't mean that warpreparation will always destabilize the state. However, it will be safe to say it is too simplistic to argue that war consolidates state power. We need to conduct more research on the specific conditions under which war consolidates/destabilizes the state.

\section{Threatening versus Non-threatening Wars: Their Different Effects on Cohesion}

Stein strongly challenges the common sense thesis that war as a great external threat increases national unity. Through his analysis of four different wars the United States fought (World War I, World War II, the Korean War and the Vietnam War), he gives us impressive insights into the impact of war on state-society relations.

46) Hoag, "Hi-Tech Armaments, Space Militarization and the Third World," Colin Creighton and Martin Shaw, eds., The Sociology of War and Peace, 84. 
According to Stein, external conflict does increase internal group cohesion, but only under certain circumstances. A number of intervening variables are necessary for the relationship to hold. It is critical that all the individual members of a group believe the external conflict constitutes a threat to the existence of the collectivity. All of the other conditions are ancillary. First, the group must have existed prior to the onset of threat. Second, its members must believe that the threat affects the entire collectivity. Third, all must believe the threat to be external as it emanates from a source outside the group. Finally, the individual must not be able to escape the threat; only cooperative behavior can reduce or eliminate it and thus protect the single member from the threat. ${ }^{47)}$

This suggests that every war is not threatening to the population. War is usually thought to be threatening to the national survival; the purpose of war, providing public good of security for the populations. However, great powers usually fight unthreatening wars. For example, the Vietnam War or the Korean War was not threatening to the survival of the United States as a nation.

As Stein says, "Wars deemed necessary to the national interest by the political elite, but in which the population perceives no threat to the existence of the nation, will not increase cohesion. Cohesion increases at war's outset only when there exists a threat to the society; without threat, cohesion will never increase. The existence of an external threat is the necessary intervening variable that transforms war into a unifying force." ${ }^{48}$ Therefore, 'threat' is not taken for granted by Stein as usual, but treated as a variable.

Not identifying war with threat but differentiating threatening war and nonthreatening war seems to be a useful conceptualization. According to this logic, we can infer that the state fighting an unthreatening (or offensive, or limited) war will have more difficulty in mobilizing resources and increasing national unity, than the state fighting a threatening (or defensive, or total) war. It is because the former is not perceived by the entire population within a society as threatening to national survival even though perceived so by the state's elites.

However, this logic will be applicable to the great powers alone which can afford to fight different kinds of wars. Most of the Third World countries cannot afford to. In most cases total war is the only option left for the small states. The same war that is unthreatening to great powers, is usually threatening to small states. For instance, the Vietnam War was a total war to the Vietnamese and the Korean War was a deadly total war to the Korean people although they were limited wars to the United States. Therefore, the impacts of war would be normally greater to small countries than to the

47) Stein, The Nation at War, 10.

48) Ibid., 87. 
great powers. Nevertheless, this does not necessarily mean that the effects of war would be always positive in the end for the Third World countries as already discussed above.

\section{Summary}

Quite a few scholars who analyzed European history support the thesis that war played an important role in state-making (as we can see through Huntington, Tilly, Giddens, Migdal, Hall, Mann and Herbst,). It is hard to flatly deny Tilly's thesis that "war made the state, and the state made the war." Mostly, war as a great external threat promoted national unity, restrained the internal resistance to increased extraction, helped capitalist development, and eventually consolidated the state and the system of the nation-state in the modern world.

However, since some changes might have occurred even without war, it runs the risk of over-generalization to argue that wartime mobilization and participation of the population directly result in the expansion of citizenship and civil rights including suffrage (as Shaw, Beckett and Price demonstrate). Moreover, despite the usual existence of "ratchet effects" or "positive displacement effects" of taxation, which means the expansion of the state's scope of activities (as Thompson and Rasler show), "negative displacement effects" are also possible (as Stein points out).

External conflict or war does increase internal group cohesion or national unity but under a certain condition only: when the population in a society believes that the external conflict constitutes a threat to the existence of the collectivity. All wars are not threatening to the population. Threat stemming from war should not be taken for granted, but should be treated as a variable. According to Stein, even threatening wars usually decrease internal cohesion except at the outset of the wars. It is because as war goes, the individual member's sacrifice increases. As a result, the number of free-riders increases.

It is also important to note that there are different kinds of wars with different effects. The state fighting an unthreatening war (or offensive war, or limited war) will have more difficulty in mobilizing resources and increasing national unity, than the state fighting a threatening war (or defensive war, or total war).

The impacts of war would be normally greater on small countries since a war is usually a total war to them. However, this does not necessarily mean that the effects of war (or war-preparation) are positive on Third World countries. It is because today's war technology is qualitatively different from that of the past. As Hoag argues, the need to acquire modern weapons could have a destabilizing effect on Third World countries 
because of their increasing dependence on great powers and financial strains.

Though it is true that wars often consolidated the states in Europe, it does not mean that wars will continue to play the same role in the future. Nor does it mean that war will necessarily consolidate the states in the Third World including Asia, Latin American and Africa. Therefore, we should avoid over-generalization.

\section{Towards Conditional Generalization on War's Role ${ }^{49)}$}

\section{Variations in Europe's Historical Experiences}

While Tilly's thesis is based on the analysis of the European experiences alone, war's role in state-building process is not only a sub-issue of the impact of the external factors on domestic politics, but also a sub-issue of the positive role of violence in human progress. To take a latter example, Moore argues democratic institutions emerged in nations where a middle-class revolution had led industrialization: no bourgeois, no democracy; violence preceded democracy. For instance, on the one hand, the French Revolution permitted France to avoid going the road of a fascist state like Germany and Japan. The Civil War also allowed America to destroy the undemocratic institutions founded upon plantation. On the other hand, India failed to produce a violent rebellion, and the lack of necessary changes for agricultural commercialization protracted economic progress. ${ }^{50)}$

Meanwhile, Downing explains the origins of democracy and autocracy in terms of constitutional arrangements as well as military dangers. That is, he offers a theory of war's role state-making. The one element of the theory is medieval constitutionalism (a basic condition for liberal democracy in Europe); the other is military mobilization. The stronger the constitutionalism, the greater the chances for democracy. However, some

49) The description in this part (IV) is partially dependent upon the following works: William Aviles, "Review," Perspectives on Politics, Vol.1, No.2 (June 2003), pp.424-425; Philip S. Gorski, "Review," Contemporary Sociology, Vol.27, No.2 (March 1998), pp.86-188; Rolf Strom-Olsen, "Review," The Sixteenth Century Journal, Vol.29, No.1 (Spring 1998), pp.119-121; Aristide R. Zolberg, "Review," The American Political Science Review, Vol.86, No.4 (December 1992), pp.1081-1082; David B. Ralston, "Review," The Journal of Modern History, Vol.67, No.1 (March 1995), pp.106-107; Gi-Wook Shin, "Review," The American Journal of Sociology, Vol.100, No.3 (November 1994), pp.826-827; J.H. Hexter, "Review," The American Historical Review, Vol.50, No.3 (April 1945), pp.501-504.

50) Barrington Moore, Jr., Social Origins of Dictatorship of Dictatorship and Democracy: Lord and Peasant In the Making of the Modern World (Beacon Press, 1966), 418 and passim. 
factors may cut the connection between war and the destruction of constitutionalismmobilization of foreign resources, burden-lightening through alliance, the benefits from advanced economy, and geography. ${ }^{51}$

Ertman provides a comparative analysis of western, central, and eastern Europe and Scandinavia, arguing that two factors-local government and sustained geo-military competition-can explain most of the variation. He distinguishes regime structure (absolutist vs. constitutionalist) from administrative infrastructure (bureaucratic vs. patrimonial), which is a major advance over previous accounts of early modern state formation. He sees the timing of geopolitical competition as crucial to the development of the state in medieval and early modern Europe. That is, in explaining the four possible outcomes he uses two main variables: (1) the timing of the onset of sustained geopolitical competition and (2) the structure of local government during the medieval period. State-builders before 1450 were compelled to rely on proprietary models of office holding that favored the development of a patrimonial infrastructure while statebuilders after 1450 drew on nonproprietary models that favored the development of a proto-bureaucratic infrastructure. ${ }^{52)}$

As we can see, theorizing on the relationship between war and state formation in Europe has made advancement from Tilly's early thesis towards Downing and Ertman's theories by which we can analyze the variations within Europe.

\section{Historical Experiences Outside of Europe}

Many believe that the system of sovereign territorial states and the roots of liberal democracy are unique to Europe. However, Hui demonstrates that China in the Spring and Autumn and Warring States periods (656-221 BC) consisted of a system of sovereign territorial states similar to early modern Europe by examining why China and Europe shared similar processes but experienced opposite outcomes. She highlights inadequacies in Kant's formulation and contingencies in the emergence of the liberal peace in the West, encourages revival of China's indigenous liberal legacy, and supports a multicultural approach to the liberal peace. ${ }^{53)}$

51) Brian Downing, The Military Revolution and Political Change (Princeton University Press, 1992), 9. Barrington Moore himself compliments in the back cover, "This book takes a big step beyond my Social Origins of Dictatorship and Democracy."

52) Thomas Ertman, Birth of the Leviathan: Building States and Regimes in Medieval and Early Modern Europe (Cambridge University Press, 1997).

53) Victoria Tin-bor Hui, War and State Formation in Ancient China and Early Modern Europe (Cambridge University Press, 2005). 
Centeno argues that most Latin American wars were limited in scale and did not consolidate the states but increased national debts since governments financed them through foreign loans rather than internal revenue. Therefore, state development in Latin America does not fit the "bellicist" model. The reason lies in the impact that different types of war can have. Centeno differentiates "limited wars" and "total wars." He looks upon total wars as conflicts that include high levels of lethalness, the militarization of society, and a moral or ideological crusade while regarding limited wars as those conflicts that lack the duration and mass mobilization of men and resources, as well as the loss of life. In order to survive in total wars, states are required to perform certain functions that potentially lay the foundation for greater state development and influence in the larger society. The relative lack of total wars in Latin America is due to the particular conditions: the geographical obstacles to state administration; the relative lack of preexisting state capacity; an export-based economic strategy that prioritized international markets over domestic ones; and the resistance of dominant classes within Latin America to unite in support of more powerful centralized authorities. ${ }^{54)}$

Hui and Centeno demonstrate that, compared with European cases, Asian and Latin American process of state formation is not necessarily peculiar; "bellicist" model of state formation cannot be applied universally due to different conditions of the regions; and the different conditions should be elaborated that result in different outcomes in cases examined.

\section{Beyønd European Experiences Towards Comprehensive Understanding}

Our understanding of the state-building process is based heavily on the European experience of war. However, we should pay attention to variations found even within Europe and avoid the sweeping generalization based on farfetched speculation from results obtained in different context. There is a widespread sense in the study of the states outside of Europe that a Western style of modern state is no longer the ultimate destination of modern political development, and that understanding the Western state can not describe the states of the rest of the world.

Boyd and Ngo examine state making projects from a uniquely Asian perspective, highlighting the particular combination of institutions and ideologies embedded in Asian state making and demonstrating their distinctiveness from the Western experience. They underline the variety and hybridism of Asian forms of the state and emphasize the

54) Miguel Angel Centeno, Blood and Debt: War and the Nation-State in Latin America (University Park: Pennsylvania State University Press, 2002), 106, 273 and passim. 
need to incorporate Asian patterns of historical change in our theorization about modern state making. They provide a comprehensive comparison of East Asia nations that accounts for their development outside of the Eurocentric viewpoint. They offer new empirical and conceptual material based on original research within the field.

Boyd and Ngo side with those who argue that the states of Asia and elsewhere have to be understood in their particularity. It is their intention to recover the important particularity of states that has been obscured by the uncritical overgeneralization and projection of understandings captive to Western forms. The parochial-turned-universal nomenclature is replicated by political science which sins doubly by overgeneralizing Western experiences and misconstruing non-Western histories. ${ }^{55)}$

In an Asian context, 'bringing the state back in' assumes the guise of the developmental state theory. This is problematic if our concern is to explain the state rather than to explain growth. In the developmentalist account of the state, attention centers on the instrumentality of state in economic development. This is highly misleading. Firstly, it takes a theory of how economies grow for a theory of the state. As such, it displaces research attention from the political to the economic. Economic development is an important aspect of state making, but it is only one aspect of state making. Secondly, the state is presented as an accomplished fact. There is neither place in the analysis for state particularity, nor is there place for the state understood as an ongoing process of state making. ${ }^{56)}$

Centeno looks at Latin America's much different experience as more relevant to politics today in regions as varied as the Balkans and sub-Saharan Africa. He challenges two extreme tendencies: to treat Latin America as a failed Europe, and to stress the utter particularism of Latin America. He pays attention to Latin America's distinctive ways of making war and the connections of warfare to state development, national identities and the nature of citizenship. He suggests that the process of state development represents such a complex and contingent process that no "all encompassing general law" or "universalistic paradigms" can adequately predict or explain outcomes for different regions and national contexts. Centeno persuasively shows the centrality of context and contingent nature of state development. ${ }^{57)}$

In a similar way, Boy and Ngo argues that political science is primarily a reflection of reflection upon Western, or even more restrictively, Anglo-Saxon political experience. It is substantially indifferent to huge body of politics, statecraft and state-making outside

55) Richard Boyd and Tak-Wing Ngo, ed., State Making in Asia (New York: Routledge, 1999), 1, 5.

56) Boyd and Ngo, ed., State Making in Asia, 6.

57) Centeno, Blood and Debt: War and the Nation-State in Latin America, 18, 165. 
of Europe. Indeed, the conceptual and theoretical flow has been exclusively one way: from the West to the non-West. ${ }^{58)}$

\section{Conclusion}

This essay examined the relationship between war as an external threat and its effects on state consolidation. As we can infer from the recent studies by Downing, Ertman, Hui, Centeno, Boyd and Ngo, it is neither desirable nor correct to apply the European experience crudely to the Third World countries (as Herbst does) and to predict that without war they will have difficulty in consolidating state power. Future war will be more devastating and as a result there will be no remaining mobilizable resources. How can a state's elites consolidate the state without remaining resources!

The South Korean state (or the North Korea state) which Herbst and Migdal illustrate as "the strong state," might have been helped by war and the continuous threat of war. However, it seems that, at least right after the Korean War, the more significant factor that consolidated the South Korean state, was external borrowing (foreign aid) with which the state started reconstruction. Maybe the external borrowing, the main revenue of the state, would not have been granted but for the international system influenced by the global Cold "War," in the context of which South Korea also participated in Vietnam War. Therefore, it is impossible to flatly deny a connection between external borrowing and war.

Relating war (or external threat from North Korea) directly to the "strength" of the South Korean state is too simplistic. We could also imagine "the roads not taken." Without American-Soviet intervention right after the end of World War II in 1945, Korea would not have been divided at first. Without the national division, there would not have been a Korean War. Then, would the one unified Korea have been a much "weaker" state because it had not confronted enough external threat?

Similarly, will the unified Germany become a weaker state than were the two separate Germanys for lack of external threat? Without American intervention in the Korean War, the South Korean state would have disappeared like the former South Vietnam. Around the time of the breakout of the war, the North Korean state was much stronger than the South Korean state. Was the South Korean state weaker because there was no external threat? Did the former South Vietnamese state lose the war because the state

58) Boyd and Ngo, ed., State Making in Asia, 1. 
was weak? If so, why was it weak despite the external threat? Did the Yugoslavian war benefit and finally consolidate the state? Did the former-Soviet Union dissolve into republics because of the weakness of the Soviet state due to lack of external threat? If so, will the United States also dissolve sometime in the future because there will be no serious external threat? Therefore, has the United States been making new enemies on purpose?

All these questions cannot be answered only by referring to the simple relationship between war and state consolidation. Though war might have played an important role, we should avoid exaggerating its positive effects by ignoring negative ones. We also need to make a counterfactual analysis as to how far the changes of the state, society and state-society relations would have evolved even without war. Interstate war as an exogenous factor might have accelerated those changes, but all the positive post-war changes cannot be attributed to war itself. We should look into various endogenous factors as well in explaining those changes, which is beyond the focus of this essay. 


\section{REFERENCES}

Almond, Gabriel A., "The International-National Connection," A Discipline Divided: Schools and Sects in Political Science (Newbury Park, London, New Delhi: Sage Publications, 1990).

Beckett, Ian F.W., "Total War," Clive Emsley, Arthur Marwick, and Wendy Simpson, ed., War, Peace and Social Change in Twentieth Century Europe (Milton Keynes-Philadelphia: Open University Press, 1989).

Boyd, Richard, and Tak-Wing Ngo, ed., State Making in Asia (New York: Routledge, 1999).

Centeno, Miguel Angel, Blood and Debt: War and the Nation-State in Latin America (University Park: Pennsylvania State University Press, 2002).

Downing, Brian, The Military Revolution and Political Change (Princeton University Press, 1992).

Ertman, Thomas, Birth of the Leviathan: Building States and Regimes in Medieval and Early Modern Europe (Cambridge University Press, 1997).

Fearon, James D., "Counterfactuals and Hypothesis Testing in Political Science," World Politics, Vol.43, No.2 (January 1991).

Giddens, Anthony, The Nation State and Violence: Volume Two of a Contemporary Critique of Historical Materialism (Berkeley: University of California Press, 1987).

Hall, John A., "War and the Rise of the West," Colin Creighton and Martin Shaw, eds., The Sociology of War and Peace (London: Macmillan, 1987).

Herbst, Jeffrey, "Responding to State Failure in Africa," International Security, Vol.21, No.3 (Winter 1996/97).

"War and the State in Africa," International Security, Vol.14, No.4 (Spring 1990).

Hintze, Otto, "Military Organization and the Organization of the State" Felix Gilbert, ed., The Historical Essays of Otto Hintze (NY: Oxford University Press, 1975).

Hoag, Paul W., "Hi-Tech Armaments, Space Militarization and the Third World," Colin Creighton and Martin Shaw, eds., The Sociology of War and Peace (London: Macmillan, 1987).

Howard, Michael, War in European History (New York: Oxford University Press, 1976).

Hui, Victoria Tin-bor, War and State Formation in Ancient China and Early Modern Europe (Cambridge University Press, 2005). 
Huntington, Samuel P., Political Order in Changing Societies (New Haven and London: Yale University Press, 1968).

Jervis, Robert, System Effects: Complexity in Political and Social Life (Princeton, New Jersey: Princeton University Press, 1997).

, "The Future of World Politics: Will It Resemble the Past?" International Security, Vol.16, No.3 (Winter 1991/92).

Joseph, Richard, and Jeffrey Herbst, "Correspondence: Responding to State Failure in Africa," International Security, Vol.22, No.2 (Fall 1997).

Knorr, Klaus, "Threat Perception," Klaus Knorr, ed., Historical Dimensions of National Security Problems (Lawrence: Published for the National Security Education Problem by the University Press of Kansas, 1976).

Lasswell, Harold D., "The Garrison State," The American Journal of Sociology, Vol.46, No.4 (January 1941).

Levy, Jack S., and Michael Barnett, "Domestic Sources of Alliances and Alignment: the Case of Egypt, 1962-73," International Organization, Vol.45, No.3 (Summer 1991).

Mann, Michael, "Capitalism and Militarism," Michael Mann, States, War and Capitalism (Basil Blackwell, 1988).

"War and Social Theory: Into Battle with Classes, Nations and States," Colin Creighton and Martin Shaw, eds., The Sociology of War and Peace (London: Macmillan, 1987).

Migdal, Joel S., Strong Societies and Weak States: State-Society Relations and State Capabilities in the Third World (Princeton, New Jersey: Princeton University Press, 1988).

Moore, Barrington, Jr., Social Origins of Dictatorship of Dictatorship and Democracy: Lord and Peasant In the Making of the Modern World (Beacon Press, 1966).

Mueller, John, Retreat from Doomsday: The Obsolescence of Major War (BasicBooks, 1989).

Nef, J.U., War and Human Progress (Cambridge, Mass.: Harvard University Press, 1950).

Powell, Robert, "Guns, Butter, and Anarchy," American Political Science Review, Vol.87, No.1 (March 1993).

Price, Kath, "What did you do in the War, Mam?: Woman Steelworkers at the Consett Iron Company during the Second World War," Colin Creighton and Martin Shaw, eds., The Sociology of War and Peace (London: Macmillan, 1987). 
Schroeder, Paul W., "Alliances, 1815-1945: Weapons of Power and Tools of Management," Klaus Knorr, ed., Historical Dimensions of National Security Problems (Lawrence: Published for the National Security Education Problem by the University Press of Kansas, 1976).

Seeley, John Robert, An Introduction to Political Science (London: Macmillan, 1886).

Shaw, Martin, "The Rise and Fall of the Military-Democratic State: Britain 1940-85," Colin Creighton and Martin Shaw, eds., The Sociology of War and Peace (London: Macmillan, 1987).

Snyder, Glenn H., Alliance Politics (Ithaca and London: Cornell University Press, 1997). "Alliances, Balance, and Stability," International Organization, Vol.45, No.1 (Winter 1991).

"Alliance Theory: A Neorealist First Cut," Journal of International Affairs, Vol.44, No.1 (Spring 1990).

"The Security Dilemma in Alliance Politics," World Politics, Vol.36, No.4 (July 1984).

Spruyt, Hendrik, The Sovereign State and Its Competitors: An Analysis of Systems Change (Princeton, NJ: Princeton University Press, 1994).

Stein, Arthur A., The Nation at War (Baltimore and London: The Johns Hopkins University Press, 1978, 1980).

Tetlock, Philip E., and Aaron Belkin, ed., Counterfactual Thoughts Experiments in World Politics: Logical, Methodological, and Psychological Perspectives (Princeton, New Jersey: Princeton University Press, 1996).

Thompson, William R., and Karen A. Rasler, "War Making and State Making: Governmental Expenditures, Tax Revenues, and Global Wars,” American Political Science Review, Vol.79, No.2 (June 1985).

Tilly, Charles, Coercion, Capital, and European States, AD 990-1990 (Cambridge, Massachusetts: Basil Blackwell, 1990). "War Making and State Making as Organized Crime," Evans, Peter B.,

Dietrich Rueschemeyer, and Theda Skocpol, eds., Bringing the State Back In (Cambridge University Press, 1985).

"Reflections on the History of European State-Making," Charles Tilly, ed., The Formation of National States in Western Europe (Princeton University Press, 1975). 
Walt, Stephen M., "Alliance Formation in Southwest Asia: Balancing and Bandwagoning in Cold War competition," Robert Jervis and Jack Snyder, ed., Dominoes and Bandwagons: Strategic Beliefs and Great Power Competition in the Eurasian Rimland (New York/ Oxford: Oxford University Press, 1991).

"Alliances in Theory and Practice: What Lies Ahead?" Journal of International Affairs, Vol.43, No.1 (Summer-Fall 1989).

, The Origins of Alliances (Ithaca and London: Cornell University Press, 1987). 